\title{
Analysis of the impact of selected determinants on brand value
}

\author{
Katarina Janoskova \\ Department of Economics, University of Zilina \\ Slovak Republic \\ katarina.janoskova@,fpedas.uniza.sk \\ Jana Kliestikova \\ Department of Economics, University of Zilina \\ Slovak Republic \\ jana.kliestikova@fpedas.uniza.sk
}

Abstract. Brand is considered to be one of the most important assets of any company and therefore determination of its value is of a great importance. There are many methods for determining brand value. Each of them is based on different inputs that determine the resulting brand value. The aim of this paper is to test the selected financial indicators that we expect to significantly affect the resulting value of a brand. In our research, we tested whether there is a statistically significant relationship among 20 selected financial indicators and the value of the brands of five companies in the automotive industry (Honda, BMW, Toyota, Daimler, Nissan), while we took into account three different brand values calculated by three consulting groups (Interbrand, Brand Finance, Millward Brown). After application of the selected statistical methods (correlation analysis and hypothesis testing of the correlation coefficient), we concluded that there exists a strong positive linear statistical relationship between the value of brand and revenue. Also, we observed a strong negative linear statistical relationship between brand value and free cash flow. Through application of hypotheses' testing of correlation coefficients we have proved that it is inappropriate to take hasty conclusions based on the use of only one statistical method, as in the case of our research, we greatly reduced our previous results by applying an additional statistical system.

Keywords: brand, brand value, financial indicator, correlation, linear relationship, statistical methods.

JEL Classification: G21, L26, O16 


\section{INTRODUCTION}

Brand management is a continuous process that integrates all activities, procedures and tools applied to increase brand value. If brand management becomes inefficient, there may be a situation known as “commodity slide" (McDonalds \& Wilson, 2011).

Then, the importance of the brand gradually disappears; it is not a significant attribute of customer buying decision anymore because the product is no longer unique in relation to competitive offers. In this situation the brand owner can't apply a high trading margin. It is also clear from this that any strong brand may lose its position if it is not being continuously developed and managed in a right way. It is vital to understand the meaning of brand value and its determinants as it serves as a tool in determining marketing strategy in any segment or at any target market.

Therefore, it is essential for companies to pay attention to the development of their brand values as well as to the development of those determinants which influence brand value the most. Several financial and non-financial indicators determine brand value. The portfolio of indicators depends on the used brand valuation method. Our research focuses only on investigating the impact of financial indicators on brand value.

The purpose of this study is to investigate the relation between brand value of the selected prestigious brands within the automotive industry (Honda, Daimler, BMW, Nissan, Toyota) and their selected financial indicators.

The goal is to find out which of the selected financial indicators have a statistically significant impact on brand value, taking into account the brand values calculated by three different organizations (Interbrand, Brand Finance, Millward Brown).

\section{LITERATURE REVIEW}

Brands are one of the most important company's valuable intangible assets (Chica et al., 2016; Keller \& Lehmann, 2006; Backhaus \& Tikoo, 2004) and play a vital function in building up a good external image of enterprises (Li \& Wang, 2016). A brand is a distinctive name for which the consumer has a higher willingness to pay than for otherwise similar products (Keller, 2012 in Dutordoir et al., 2015).

Building strong brands should be main goal for entrepreneurs, because it gives a number of advantages. The product and the producer brand is the basic determinant of customer capital and company value (Caputa, 2015). Strong brands help the company establishes an identify in the market place (Aaker, 1996 in Chattopadhyay et al., 2009), reduce vulnerability to competitive actions, leading to larger margins, greater intermediary co-operation and support and brand extension opportunities (Delgago \& Ballester, 2005 in Chattopadhyay et al., 2009). A brand refers to a firm's ability to consistently deliver on its promise across all business units, regardless of the geographical scale of the enterprise (Olsen et al., 2005). Brand has the potential to be a source of a long-term sustainable competitive advantage of such an enterprise (Majerova \& Kliestik, 2015). Measuring the value of brand is very important and difficult activity. While brand is the sum of all experiences from a customer perspective, brand value indicates what the brand means to a main firm. Highr brand value can be beneficial for both customers and firms (Tuominen, 1990 in Chung et al., 2013). Brand can create value for their own companies according to two ways, not only directly by increasing the sales volumes and profitability by utilizing resources and capabilities but also indirectly by lowering costs such as human resources (Raggio and Leone, 2007 in Chung et al., 2013). Brand value is defined as the difference in equilibrium profit between the brand in question and its counterfactual unbranded equivalent on search attributes (Avi, G. et al., 2009).

Many authors presented a lot of brand valuation methods and each one is based on several different indicators. On basis of literature we hypothesize positive and negative relationships between brand value 
and several financial indicators. For example Muqaddas \& Ahmad (2016) investigated the impact of advertising \& promotion, research \& development and profitability (return on assets) on brand equity. Interaction between research \& development reputation and corporate brand value investigated also Gassmann et al. (2009). Beccacece et al. (2006) presented brand valuation models based on several financial indicators such as sales, cost of sales, advertising and promotion, operating cost, cash flow etc. Influence of scientific and technological innovation on brand value investigated Wang and Su (2016). Caputa (2015) indicated the relations between the brand value in a marketing and financial dimension. Relationship between the brand value and selected determinants of financial performance of company was presented by Peterson \& Jeong (2010). Comparison of two brand value measures (EquiTrend and Interbrand) during the financial crisis was presented by Johansson et al. (2012). Gui et al. (2013) in their work deal with the selected determinants of proactive brand equity valuation methodology, that offer decision-makers a robust and effective tools to enable improved resource allocation decision that maximize overall brand value. Several studies find interaction between brand value and firm value. Dutordoir et al (2015) developed and tested a new framework on the contingencies affecting the impact of brand value changes on stock returns.

\section{METHODOLOGY}

On basis of literature, we hypothesize relationship between brand value and some financial and nonfinancial determinants. The most frequently presented non-financial indicators determining the brand value are as follows: 1. Brand loyalty. 2. Brand awareness. 3. Perceived Quality. 4. Brand association. 5. Other proprietary brand assets.

However, our goal is testing only the relationship between brand value and much more financial indicators.

The study is based on historical data to identify the relationship of defined variables. The quantitative methods are used to analyse the data.

To meet the stated goal, which is investigation of relationships between the brand value and selected financial indicators, we applied an analogical statistical apparatus (characteristics of descriptive statistics, correlation analysis) as the authors did in their works (Svabova \& Kral, 2016; Bartosova \& Kral, 2016; Svabova \& Durica, 2016; Hindls et al., 2003; Pacakova et al., 2003).

The relationship between brand value and selected financial indicators were tested on a sample of car brands in time horizon of 10 years (2006-2015).

When analysing the correlation we have worked with 30 financial indicators. After initial calculations, the choice was narrowed down to the following 20 representative financial indicators:

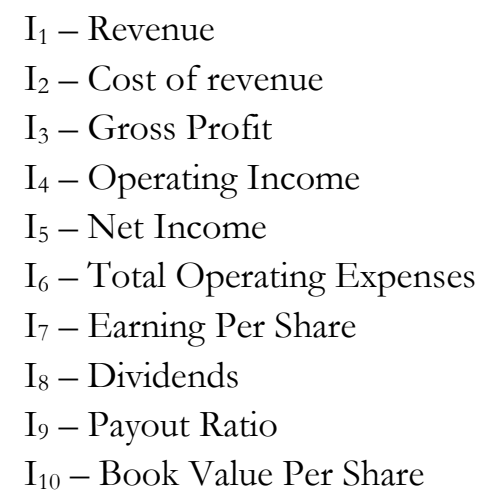

$$
\begin{aligned}
& \mathrm{I}_{11}-\text { Operating Cash Flow } \\
& \mathrm{I}_{12}-\text { Free Cash Flow } \\
& \mathrm{I}_{13}-\text { Working Capital } \\
& \mathrm{I}_{14}-\text { Asset Turnover } \\
& \mathrm{I}_{15}-\text { Return on Assets } \\
& \mathrm{I}_{16}-\text { Financial Leverage } \\
& \mathrm{I}_{17}-\text { Return on Equity } \\
& \mathrm{I}_{18}-\text { Return on Invested Capital } \\
& \mathrm{I}_{19}-\text { Invested Coverage } \\
& \mathrm{I}_{20}-\text { Price/Earnings }
\end{aligned}
$$

The values of the financial indicators of selected brands for the period 2006-2015, were drawn from www.morningstar.com. 
Selected financial indicators were tested in relation to the assessed values of the selected brands by the consulting groups Interbrand (I), Brand Finance (BF) a Millward Brown (MB). Due to the fact that brand value is determined for the year ahead based on historical data from the previous year, we took into account the brand values calculated for the period 2007-2016.

Due to the unavailability of data, we were forced to limit the sample of analysed brands of the automotive industry to five:

- Honda Motor Co Ltd ADR (HMC),

- Bayerische Motoren Werke AG (BMW),

- Toyota Motor Corp ADR (TM),

- Daimler AG (DDAIF),

- Nissan Motor Co Ltd ADR (NSANY).

The Pearson's correlation coefficient is applied to find out whether there is a linear relationship between the absolute brand value and selected financial indicators for the reporting period 2006-2015.

When interpreting the calculations of correlation coefficients, we draw on the following guidelines (Table 1):

Table 1

Degree of Correlation

\begin{tabular}{|c|c|}
\hline Correlation Coefficient & Degree of Correlation \\
\hline $0-0.3$ & low \\
\hline $0.3-0.7$ & medium \\
\hline $0.7-1.0$ & high \\
\hline
\end{tabular}

Not even a high value of correlation coefficient does automatically imply a causal relationship between variables. Particularly with a small scale selection, which is the case of our research, it is needed to assess the results obtained with great care so that we do not come to early wrong conclusions. For this reason, we will conduct tests of hypotheses of correlation coefficient at the significance level of $5 \%$ using the test criteria U (Hindls et al., 2003).

$$
U=\frac{\left|z_{r}-z_{\rho_{0}}\right|}{D\left(z_{r}\right)}=\left|1.1513 \log \frac{1+r_{y x}}{1-r_{y x}}-1.1513 \log \frac{1+\rho_{y x}}{1-\rho_{y x}}-\frac{\rho_{y x}}{2(n-1)}\right| \sqrt{n-3}
$$

We set the following tasks to achieve the main goal and confirm the results:

- Testing correlation of values of the selected financial indicators $\left(\mathrm{I}_{1}-\mathrm{I}_{20}\right)$ of individual brands (HMC, BMW, TM, DDAIF, NSANY) in relationship to the value of a brand quantified by consulting groups (Interbrand, Brand Finance a Millward Brown) during analysed period (2006-2015).

- Determination of maximum and minimum values of the correlation coefficient and subsequent evaluation of financial indicators, which have the highest positive and negative linear correlation to the brand value established by individual consulting groups.

- Identification of financial indicators, which have the lowest positive or negative linear correlation to the brand value.

- The subsequent in-depth analysis of the selected financial indicators for which a strong correlation to the brand value has been proven. 


\section{EMPIRICAL RESULTS AND DISCUSSION}

The research results present relationship between the financial indicators and the brand value quantified by three consulting groups. The aim was to prove, among which financial indicators and brand value is the highest positive or negative linear correlation. Summary results are shown in the following table (Table 2).

Table 2

Financial indicators with the highest positive and negative linear correlation to the brand value

\begin{tabular}{|l|c|c|c|c|c|c|}
\hline \multirow{2}{*}{ Brand } & \multicolumn{2}{|c|}{ Interbrand } & \multicolumn{2}{c|}{ Brand Finance } & \multicolumn{2}{c|}{ Millward Brown } \\
\cline { 2 - 7 } & Pearson max & Pearson min & Pearson max & Pearson min & Pearson max & Pearson min \\
\hline \multirow{3}{*}{ Honda } & 0.587 & -0.386 & 0.709 & -0.521 & 0.797 & -0.827 \\
\cline { 2 - 7 } & $\mathrm{I}_{2}$ & $\mathrm{I}_{12}$ & $\mathrm{I}_{10}$ & $\mathrm{I}_{12}$ & $\mathrm{I}_{14}$ & $\mathrm{I}_{10}$ \\
\hline \multirow{3}{*}{ BMW } & 0.985 & -0.928 & 0.973 & -0.879 & 0.913 & -0.847 \\
\cline { 2 - 7 } & $\mathrm{I}_{1}$ & $\mathrm{I}_{11}$ & $\mathrm{I}_{10}$ & $\mathrm{I}_{11}$ & $\mathrm{I}_{6}$ & $\mathrm{I}_{16}$ \\
\hline \multirow{3}{*}{ Toyota } & 0.869 & -0.725 & 0.934 & -0.516 & 0.732 & -0.877 \\
\cline { 2 - 7 } & $\mathrm{I}_{1}$ & $\mathrm{I}_{8}$ & $\mathrm{I}_{10}$ & $\mathrm{I}_{14}$ & $\mathrm{I}_{2}$ & $\mathrm{I}_{16}$ \\
\cline { 2 - 7 } & 0.972 & -0.696 & 0.869 & -0.767 & 0.871 & -0.601 \\
\hline \multirow{2}{*}{ Nissan } & $\mathrm{I}_{1}$ & $\mathrm{I}_{11}$ & $\mathrm{I}_{1}$ & $\mathrm{I}_{9}$ & $\mathrm{I}_{1}$ & $\mathrm{I}_{9}$ \\
\cline { 2 - 7 } & 0.949 & -0.651 & 0.922 & -0.752 & 0.904 & -0.797 \\
\hline
\end{tabular}

Source: Authors' results.

Out of the 15 financial indicators, which show the highest positive linear correlation is up to 14 from the interval $<0.7,1.0>$ reflecting a high degree of linear correlation between these indicators and brand value. Indicator $I_{1}-$ Revenue reached the highest multiplicity based on which, we assume that precisely this financial indicator has the most significant impact on brand value in terms of positive linear correlation.

Value development of indicator $\mathrm{I}_{1}$ - Revenue of BMW and brand value of BMW established by Interbrand is graphically illustrated as an example (Figure 1), since in this case we measured the highest value of the Pearson correlation coefficient (0.985). In this case the coefficient of determination is 0.97 . It reflects that differences in brand value of BMW are caused by $97 \%$ by a difference in the explanatory variable $\mathrm{I}_{1}$ - Revenue.

The second most numerous indicator is $\mathrm{I}_{10}-$ Book Value Per Share. Value development of indicator $\mathrm{I}_{10}$ - Book Value Per Share of BMW and brand value of BMW quantified by Brand Finance is graphically illustrated as an example (Figure 2), since in this case we measured the highest value of the Pearson correlation coefficient (0.973). In this case the coefficient of determination is 0.948 . It reflects that differences in brand value of BMW are caused by $94.8 \%$ by a difference in the explanatory variable $\mathrm{I}_{10}-$ Book Value Per Share. 


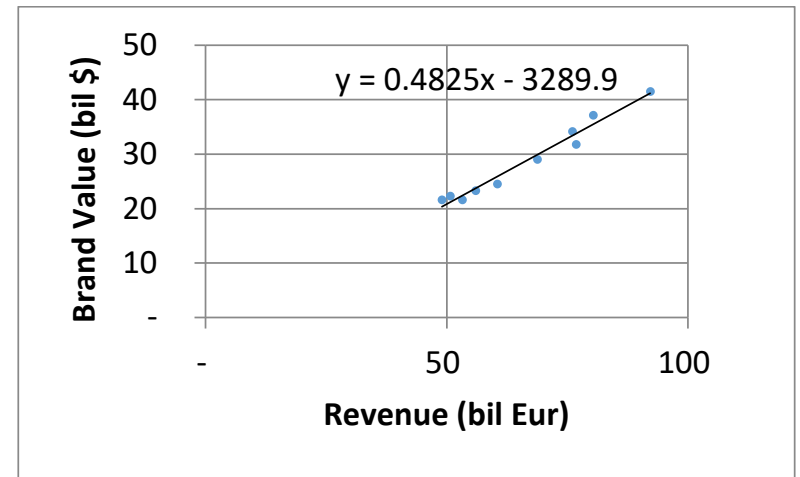

Figure 1. Correlation between Brand Value and Revenue

Source: Authors' results.

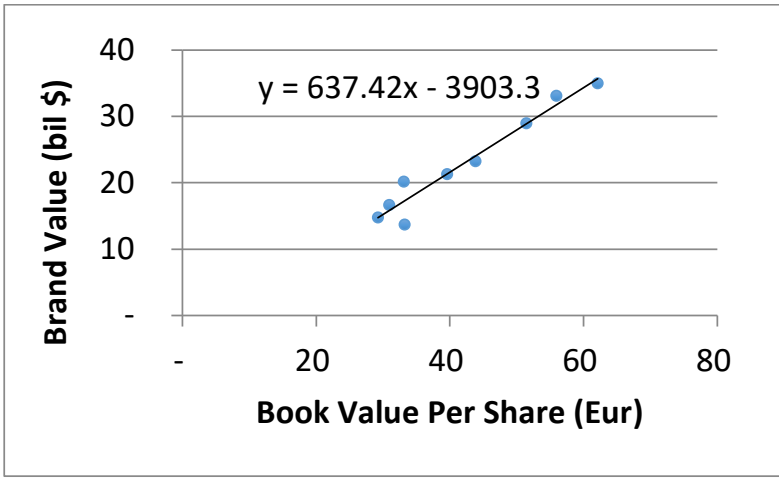

Figure 2. Correlation between Brand Value and Book Value Per Share

Source: Authors' results.

The situation is different within the negative linear correlation. Out of the 15 financial indicators, which show the highest negative linear correlation is only eight from the interval $<-0.7,-1.0\rangle$ and up to 10 from the interval $<-0.3,-0.7>$ reflecting a medium degree of negative linear correlation between these indicators and brand value. Indicator $\mathrm{I}_{12}$ - Free Cash Flow reached the highest multiplicity based on which, we assume that precisely this financial indicator has the most significant impact on brand value, in terms of negative linear correlation. Value development of indicator $\mathrm{I}_{12}-$ Free Cash Flow of Nissan in relation to the brand value of Nissan quantified by Millward Brown is graphically illustrated as an example (Figure 3), since in this case we measured the highest value of the Pearson correlation coefficient (-0.827). In this case the coefficient of determination is relatively low (0.635). It reflects that differences in brand value of Nissan are caused by $63.5 \%$ by a difference in the explanatory variable $\mathrm{I}_{12}$ - Free Cash Flow. The second most numerous indicator is $\mathrm{I}_{11}$ - Operating Cash Flow. Value development of indicator $\mathrm{I}_{11}$ - Operating Cash Flow of BMW in relation to the brand value of BMW quantified by Interbrand is graphically illustrated as an example (Figure 4), since in this case we measured the highest value of the Pearson correlation coefficient $(-0.928)$. In this case the coefficient of determination is 0.861 . It reflects that differences in brand value of BMW are caused by $86.1 \%$ by a difference in the explanatory variable $\mathrm{I}_{11}$ - Operating Cash Flow.

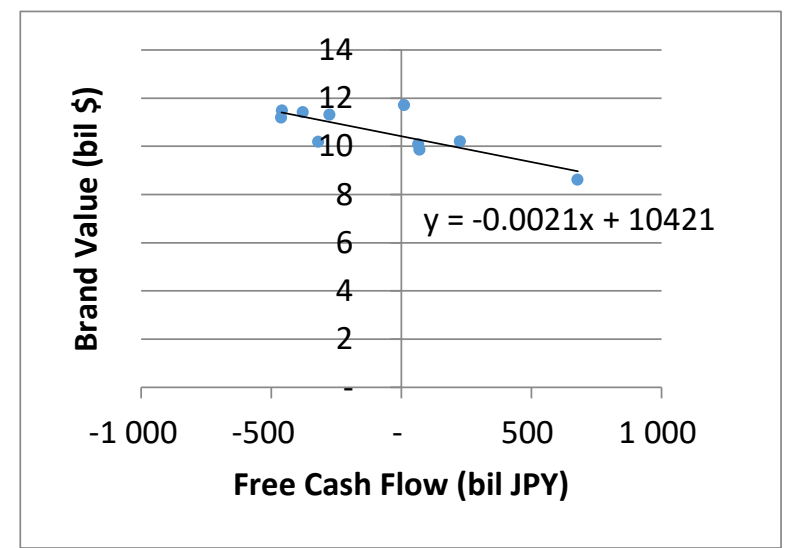

Figure 3. Correlation between Brand Value and Free Cash Flow

Source: Authors' results.

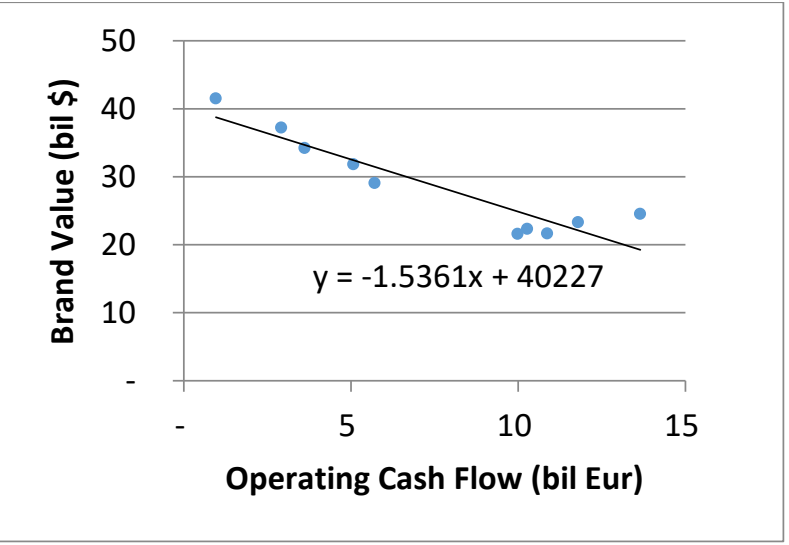

Figure 4. Correlation between Brand Value and Operating Cash Flow

Source: Authors' results. 
Based on the above we can conclude that a randomly selected financial indicators show mostly positive linear correlation to the brand value.

We also identified a financial indicator for each brand, the value of which correlates least with the brand value, i.e. the value of Pearson correlation coefficient is closest to zero. The following table shows summary of financial indicators that affect the brand value least.

Financial indicators with the lowest rate of correlation in relation to the brand value

\begin{tabular}{|c|c|c|c|}
\hline Brand & Interbrand & Brand Finance & Millward Brown \\
\hline \multirow{2}{*}{ Honda } & 0.002 & 0.015 & -0.044 \\
\cline { 2 - 4 } & $\mathrm{I}_{6}$ & $\mathrm{I}_{4}$ & $\mathrm{I}_{11}$ \\
\hline \multirow{2}{*}{ BMW } & -0.249 & -0.200 & -0.253 \\
\cline { 2 - 4 } & $\mathrm{I}_{14}$ & $\mathrm{I}_{9}$ & $\mathrm{I}_{12}$ \\
\hline \multirow{2}{*}{ Toyota } & -0.157 & -0.098 & -0.006 \\
\cline { 2 - 4 } & $\mathrm{I}_{12}$ & $\mathrm{I}_{12}$ & $\mathrm{I}_{12}$ \\
\hline \multirow{2}{*}{ Daimler } & -0.107 & 0.196 & -0.005 \\
\cline { 2 - 4 } & $\mathrm{I}_{12}$ & $\mathrm{I}_{14}$ & $\mathrm{I}_{20}$ \\
\hline \multirow{2}{*}{ Nissan } & 0.196 & -0.056 & 0.091 \\
\cline { 2 - 4 } & $\mathrm{I}_{9}$ & $\mathrm{I}_{6}$ & $\mathrm{I}_{14}$ \\
\hline
\end{tabular}

Source: Authors' results.

Based on the results of partial analysis focused on identifying financial indicators with the lowest rate of influence on the brand value, we can conclude that in terms of multiplicity of indicators with value of correlation coefficient closest to zero (15 measured values), we consider indicator $\mathrm{I}_{12}$ - Free Cash Flow the indicator with lowest influence on the brand value. However, this is an indicator that showed the same multiplicity (5) in achieving the maximum values (based on our analysis), i.e. it is also an indicator with a significant impact in terms of negative linear correlation. This is a paradoxical situation, because of which we focused not only on the multiplicity of the phenomenon, but also on the absolute lowest value of indicator. Based on this criterion, we identified indicator $\mathrm{I}_{6}-$ Total Operating Expenses, which reaches a value of correlation closest to zero (0.002). Indicator $\mathrm{I}_{6}$ - Total Operating Expenses consists of three components (Research \& Development, Sales, General \& Administration, Other). The results of our analysis are compliant with the research output of Muqaddas \& Ahmad (2016), who state that research and development has non-significant impact on brand equity. Although their research was focused on the IT industry, but also in the automotive industry we agree with their statement that ,Research and development will not have significant impact on brand equity but still it has a positive relationship with brand equity. The positive relationship suggesting that $R \& D$ expenditure may produce positive returns in the long run; payoffs may take a longer time to reward R\&D investment.“ (Muqaddas \& Ahmad, 2016).

In the next section we will focus on a deeper analysis of those financial indicators that we have identified as indicators with strongest linear relationship relative to the brand value.

The first indicator with the greatest impact is $I_{1}-$ Revenue. We verify at the level of significance $5 \%$, if there is a strong linear relationship between Revenue and Brand Value expressed by a coefficient of correlation equal to 0.8 (extremely strong positive linear relationship). Within the 15 measurements (5 brands $x 3$ consulting groups) eight values of the correlation coefficient greater than 0.8 were identified. We set the null hypothesis in the form of $\mathrm{H}_{0}: \varrho_{\mathrm{yx}}=0.8$ and due to the nature of the problem, we have defined 
an alternative hypothesis $\mathrm{H}_{1}: \varrho_{\mathrm{yx}}>0.8$. Substituting into relation of the test criterion (1), we came to the following results (Table 4).

Table 4

Testing the hypotheses of correlation coefficients $\left(\mathrm{I}_{1}-\right.$ Revenue)

\begin{tabular}{|c|c|c|c|c|}
\hline \multirow{2}{*}{ Brand } & Test criterion & Interbrand & Brand Finance & Millward Brown \\
\hline \multirow{2}{*}{ Honda } & $\varrho_{y x}$ & 0.5586 & 0.2028 & 0.2326 \\
\cline { 2 - 5 } & $\mathrm{U}$ & - & - & - \\
\hline \multirow{2}{*}{ BMW } & $\varrho_{\mathrm{yx}}$ & $\mathbf{0 . 9 8 5 2 *}$ & $\mathbf{0 . 9 4 2 1 *}$ & 0.3979 \\
\cline { 2 - 5 } & $\mathrm{U}$ & $\mathbf{3 . 4 5 6 * *}$ & 1.623 & - \\
\hline \multirow{2}{*}{ Toyota } & $\varrho_{\mathrm{yx}}$ & $\mathbf{0 . 8 6 9 3 *}$ & 0.7037 & - \\
\cline { 2 - 5 } & $\mathrm{U}$ & 0.496 & - & $\mathbf{0 . 8 7 0 6 *}$ \\
\hline \multirow{2}{*}{ Nissan } & $\varrho_{\mathrm{yx}}$ & $\mathbf{0 . 9 7 2 6 *}$ & $\mathbf{0 . 8 6 8 5 *}$ & $\mathbf{3 . 7 9 1 * *}$ \\
\cline { 2 - 5 } & $\mathrm{U}$ & $\mathbf{2 . 6 3 4 * *}$ & 0.962 & $0.9041^{*}$ \\
\cline { 2 - 5 } & $\varrho_{y x}$ & $0.8231^{*}$ & 0.4790 & 0.928 \\
\hline
\end{tabular}

Source: Authors' results. ${ }^{*} \varrho_{\mathrm{yx}}>0.8$ (extremely strong relationship), ${ }^{* *} \mathrm{U}>1.645$ (critical value).

Application of test criterion $\mathrm{U}$ for set $\mathrm{H}_{1}$ can be done just with values $\varrho_{\mathrm{yx}}>0.8$. The values of the test criterion $U$ are then compared with the critical table value, which is the level of significance $5 \% u_{0.95}=$ 1.645. As we can see in table 4, eight values were initially identified, in which $\varrho_{y x}>0.8$ that means that we considered them to be indicators with extremely strong relationship to the value of the brand. However, after the test of the hypothesis, we have reduced the number to three, because only three of them reached the value of the test criterion that was greater than the critical value.

Hypothesis testing of the correlation coefficient enables to generalize the results for the whole set only on the basis of a selective choice. In our case we can present following test results:

- We have proved a statistically significant relationship of the indicator $\mathrm{I}_{1}$ - Revenue of the brand BMW in relationship to the value of this brand quantified by consulting group Interbrand. In practice, this means that if an enterprise shows an increase in this indicator during a specified period, then we can expect on the level of significance of $5 \%$, that the value of the brand quantified by Interbrand for the coming year will increase, and vice versa.

- We have proved a statistically significant relationship of the indicator $\mathrm{I}_{1}$ - Revenue of the brand Daimler in relationship to the value of this brand quantified by consulting groups Interbrand and Millward Brown. In practice, this means that if an enterprise shows an increase in this indicator during a specified period, then we can expect on the level of significance of $5 \%$, that the value of the brand quantified by Interbrand and Millward Brown for the coming year will increase, and vice versa.

- Despite initial testing, which proved a strong correlation between indicators $\mathrm{I}_{1}$ - Revenue of BMW and Daimler in relation to the brand value quantified by Brand Finance, hypothesis testing of the correlation coefficient has not confirmed this strong relationship. The same situation occurred when testing the relationship between indicator $\mathrm{I}_{1}$ - Revenue of Toyota and Nissan in relationship to the value of this brand quantified by Interbrand and of the indicator $\mathrm{I}_{1}$ - Revenue of Nissan in relationship to the value of this brand quantified by Millward Brown.

The results of our research show that the development of a company's revenue in a given year affects the brand value quantified for the following year. Revenue is an indicator that can be called as cumulative, 
because it includes the impact of multiple financial and non-financial factors. The positively evolving values of the individual factors influencing the brand value are reflected in increased demand for products and therefore in increased revenues. This hypothesis was confirmed by statistical testing. Revenue is a significant indicator whose value is directly proportional to the brand value. It turned out that the value of the brand is a reflection of the brand's value in terms of current and future income. It is important to note that the relationship between these two variables is interactive. Revenues affects the brand value and, on the other hand, the brand value affects the revenues.

At the time of the economic crisis of 2008-2010, the automotive industry was one of the most affected sectors of national economies. All evaluated brands had lower revenues at the time of crisis, which also resulted decrease in brand values calculated by consulting groups. It is necessary to highlight the impact of macroeconomic development on the brand value and at the same time on the development of corporate revenues. We can reaffirm the interactive relationship between these variables.

We proceeded the same way with the second indicator $\mathrm{I}_{10}$ - Book Value Per Share. Here again, there was a reduction of the values from five, in which was the value of $\varrho_{y x}>0.8$, to three. Only in three cases, the value of the test criterion is greater than the critical value. Hypothesis testing of the correlation coefficient confirmed the strong relationship between the indicator $\mathrm{I}_{10}$ - Book Value Per Share of BMW and the values of this brand quantified by Interbrand a Brand Finance and between this indicator of Honda and the value of this brand quantified by Millward Brown. A strong statistical relationship between indicator $\mathrm{I}_{10}$ - Book Value Per Share of Toyota and the value of this brand quantified by Brand Finance was not confirmed. A strong statistical relationship between indicator $\mathrm{I}_{10}-$ Book Value Per Share of Nissan and the value of this brand quantified by Interbrand was also not confirmed.

\section{CONCLUSION}

The brand is considered to be a significant asset of each company. Therefore, determination of its value is of great importance. In practice, different methods are used to quantify the value of a brand. Using them multiple times may lead to quite different value estimations of a brand. Many world-famous consulting groups are dedicated to quantifying the value of brand, such as Interbrand, Brand Finance and Millward Brown, with the values of which we have worked in our research above.

The goal was to identify whether there is a statistically significant linear relationship among the selected financial indicators and the value of the selected brands from the automotive industry. And if so, to identify whether this relationship is positive, or negative. When examining the relationship, we have tested 20 financial indicators of five brands (Honda, BMW, Toyota, Daimler and Nissan) for the period of 2006 2015 in relation to the value of these brands quantified by the three mentioned above consulting groups. By that, we also pointed attention to the differences between the values of these brands specified by different companies.

Based on the correlation analysis, we identified the financial indicators that show a strong positive and negative linear relationship with the value of the brand and at the same time, we have identified those financial indicators that demonstrate the minimal impact on brand value.

Given the fact that we have worked with a rather small-scale sample, we subjected the obtained strong statistical relationship to further testing - the hypotheses' testing of correlation coefficients.

Testing the hypothesis has proved that not all relationships, which we have previously identified as being strong based on the correlation results, are in fact strong. Thus, we narrowed the range of strong statistical correlation. It can be started that it is inappropriate to make hasty conclusions using only one statistical method. 
From this analysis, we conclude that it would be appropriate if the following research in this area will be focused on identification of common selected financial indicators of multiple brands in a specific sector (e.g. automotive) in relationship to brand value. Subsequent testing of the hypotheses on correlation coefficients could generalize whether a given financial indicators has a statistically significant dependence in relation to brand value throughout the automotive industry.

\section{ACKNOWLEDGEMENT}

The paper is the output of the project APVV-15-0505: Integrated Model of Management Support for Building and Managing the Brand Value in the Specific Conditions of the Slovak Republic.

\section{REFERENCES}

Avi, G., Qiang, L. \& Sridhar, M. (2009). Measuring Brand Value in an Equilibrium Framework. Marketing Science, 28(1), 69-86. doi: http://dx.doi.org/10.1287/mksc.1080.0376

Backhaus, K. \& Tikoo, S. (2004). Conceptualizing and researching employer branding. Career Development International, 9(5), 501-517.

Bartosova, V. \& Kral, P. (2016). A Methodological Frarmework of Financial Analysis Results Objectification in the Slovak Republic. 3rd International Conference on Business and Economics, 17, 189-197. doi: http://dx.doi.org/10.15405/epsbs.2016.11.02.18

Beccacece, F., Borgonova, E. \& Reggiani, F. (2006). Risk Analysis in Brand Valuation. doi: http://dx.doi.org/10.2139/ssrn. 931023

Caputa, W. (2015). Marketing and financial value of brand in the light of research. 10th International Conference on Applied Business Research (ICABR), 1129-1142.

Dutordoir, M., Verbeeten, F. H. M. \& De Beijer, D. (2015). Stock price reactions to brand value announcements: Magnitude and moderators. International Journal of Research in Marketing, 32(1), 34-47. doi: http://dx.doi.org/10.1016/j.ijresmar.2014.08.001

Gassmann, O., Rumsch, WC, Ruetsche, E. \& Bader, M. A. (2009). R\&D Reputation and Corporate Brand Value. Research-Technology Management, 52(4), 16-19.

Gui, H. K., Gillpatrick, T., Bloom, W. et al. (2013). Driving and Creating Brand Value Through Brand Equity Valuation. Conference on Technology Management in the IT-Driven Services (PICMET), pp. 953-964.

Hindls, R., Hronova, S. \& Seger, J. (2003). Statistika pro ekonomy. Praha: Professional Publishing.

Chattopadhyay, T., Shivani, S. \& Krishnan, M. (2009). Determinants of brand equity - A blue print for building strong brand: A study of automobile segment in India. African Journal of Marketing Management, 1(4), 109-121.

Chica, M., Cordon, O., Damas, S., Iglesias, V. \& Mingot, J. (2016). Indentimod: Modeling and managing brand value using soft computing. Decision Support Systems, 89, 41-55. doi: http://dx.doi.org/10.1016/j.dss.2016.06.007

Chung, TW, Jang, HM \& Han, JK (2013). Financial-based Brand Value of Incheon International Airport. The Asian Journal of Shipping and Logistics, 29(2) 267-286.

Johansson, J. K., Dimofte, C. V. \& Mazvancheryl, S. K. (2012). The performance of global brands in the 2008 financial crisis: A test of two brand value measures. International Journal of Research in Marketing, 29, 235-245.

Keller, K. L. \& Lehmann, D. R. (2006). Brands and branding: research findings and future priorities. Marketing Science, 25(6), 740-759. doi: http://dx.doi.org/10.1287/mksc.1050.0153

Li, JC \& Wang, FF (2016). Analysis on Brand Value Evaluation and Management. Proceedings of the 2nd International Conference on Social Science and Technology Education (ICSSTE 2016), 55, 973-976.

Majerova, J. \& Kliestik, T. (2015). Brand valuation as an important component of brand value building and managing. 4th World Conference on Business, Economics and Management (WCBEM-2015), 26, 546-552. doi: http://dx.doi.org/10.1016/S2212-5671(15)00953-3

McDonald, M. \& Wilson, H. (2011). Marketing plans: How to Prepare Them, how to Use Them. Hoboken, N.J.: Wiley \& Sons, p. 580. 
Muqaddas, M. F. \& Ahmad, I. (2016). Determinants of brand equity: an empirical study of IT industry. SEA-Practical Application of Science, IV(3/12), 555-560.

Olsen, M. D., Chung, Y., Graf, N., Lee, K. \& Madanoglu, M. (2005). Branding: Myth and reality in the hotel industry. Journal of Retail \& Leisure Property, 4(2), 146-162.

Pacakova, V. et al. (2003). Statistika pre ekonomov. Bratislava: Iura Edition.

Peterson, J. A. \& Jeong, J. (2010). Exploring the impact of advertising and R\&D expenditures on corporate brand value and firm-level financial performance. Journal of the academy of marketing science, 38(6), 677-690. doi: http://dx.doi.org/10.1007/s11747-010-0188-3

Svabova, L. \& Durica, M. (2016). Korelacna analyza prediktorov pouzitych v bankrotnych predikcnych modeloch na Slovensku. Ekonomicko-manazerske spektrum, 1, 2-11.

Svabova, L. \& Kral, P. (2016). Selection of Predictors in Bankruptcy Prediction Models for Slovak Companies. 10th International Days of Statistics and Economics, 1759-1768.

Wang, BL \& Su, ZX (2016). Study on Influence of Scientific and Technological Innovation on Brand Value. Empirical Study on Shaanxi Brand Enterprises. 2016 International Conference on Management, Economics and Social Development (ICMESD 2016), 1052-1057. 